\section{Effects of Cover Crops, Compost, and Vermicompost on Strawberry Yields and Nitrogen Availability in North Carolina}

\author{
John E. Beck ${ }^{1}$, Michelle S. Schroeder-Moreno ${ }^{2,5}$, \\ Gina E. Fernandez ${ }^{3}$, Julie M. Grossman ${ }^{4}$, and Nancy G. Creamer ${ }^{3}$
}

ADDITIONAL INDEX WORDs. Fragaria $\times$ ananassa, sustainable agriculture, crop rotation, methyl bromide alternative, organic transition practices, nutrient management

SUMMARY. Summer cover crop rotations, compost, and vermicompost additions can be important strategies for transition to organic production that can provide various benefits to crop yields, nitrogen $(\mathrm{N})$ availability, and overall soil health, yet are underused in strawberry (Fragaria $\times$ ananassa) production in North Carolina. This study was aimed at evaluating six summer cover crop treatments including pearl millet (Pennisetum glaucum), soybean (Glycine max), cowpea (Vigna unguiculata), pearl millet/soybean combination, pearl millet/cowpea combination, and a no cover crop control, with and without vermicompost additions for their effects on strawberry growth, yields, nutrient uptake, weeds, and soil inorganic nitratenitrogen and ammonium-nitrogen in a 2 -year field experiment. Compost was additionally applied before seeding cover crops and preplant $\mathbf{N}$ fertilizer was reduced by $67 \%$ to account for organic $N$ additions. Although all cover crops (with compost) increased soil $\mathrm{N}$ levels during strawberry growth compared with the no cover crop treatment, cover crops did not impact strawberry yields in the first year of the study. In the 2 nd year, pearl millet cover crop treatments reduced total and marketable strawberry yields, and soybean treatments reduced marketable strawberry yields when compared with the no cover crop treatment, whereas vermicompost additions increased strawberry biomass and yields. Results from this study suggest that vermicompost additions can be important sustainable soil management strategies for transitional and certified organic strawberry production. Summer cover crops integrated with composts can provide considerable soil $\mathrm{N}$, reducing fertilizer needs, but have variable responses on strawberry depending on the specific cover crop species or combination. Moreover, these practices are suitable for both organic and conventional strawberry growers and will benefit from longer-term studies that assess these practices individually and in combination and other benefits in addition to yields.

$\mathrm{I}$ n 2014, the total value for strawberries reached nearly $\$ 2.8$ billion in the United States, $\approx \$ 2.6$ billion of which came from freshmarket berries [U.S. Department of Agriculture (USDA), 2015]. Similar to other crops, there has been a growing demand for organic strawberries with a reported farm gate price premium $\approx 55 \%$ for organic strawberries between 2007 and 2012 (Carroll et al., 2012). Although there are a variety of studies examining sustainable and organic practices for strawberry production (Reganold et al., 2010; Werner et al., 1990), much of this research is focused in California and may not be applicable to the challenging environmental conditions in North Carolina (NC) or the southeastern United States (SE). North Carolina is one of the top fresh-market strawberry-producing states (North Carolina Department of Agriculture Agricultural Statistics, 2012) in the SE where strawberries are usually produced on small- to midsized family farms (Sydorovych et al., 2006). The focus on direct sales and pick-your-own operations in NC has resulted in strawberry production systems located in the same fields year after year (Poling, 1993). Moreover, the warm climate, high humidity, poor fertility, and acidic soils in NC exacerbate soilborne pathogen and weed problems, especially when strawberry production is not rotated between fields. The combination of market forces, lack of rotation, and inherent pest pressures has resulted in strawberry production systems that depended on previous methyl bromide fumigation and now other fumigation strategies to control pests in NC. Furthermore, these chemically based controls are not applicable to organic production. There is a critical need for research on soil and pest management strategies relevant for organic producers, those interested in transitioning to organic certification, and those seeking alternatives to fumigation practices that improve the long-term viability of strawberry production systems in NC and the SE.

Biologically based soil management practices, such as cover crop rotations, additions of compost and vermicompost are important practices in organic systems, but may also serve as important transitions from fumigation in conventional strawberry systems. These soil management practices can increase organic matter additions, soil fertility, and enhance beneficial soil organisms, potentially reducing the amount of synthetic fertilizer inputs in conventional systems. As fumigation and pesticide restrictions increase, researches on practices that are cost-effective and reduce environmental impacts are critical for the future of strawberry production in the SE and beyond.

Although cover crop rotations are common cultural practices in organic crop production that provide

\begin{tabular}{llll}
\hline $\begin{array}{l}\text { Units } \\
\text { To convert U.S. to SI, } \\
\text { multiply by }\end{array}$ & U.S. unit & SI unit & $\begin{array}{l}\text { To convert SI to U.S., } \\
\text { multiply by }\end{array}$ \\
\hline 29.5735 & $\mathrm{fl} \mathrm{oz}$ & $\mathrm{mL}$ & 0.0338 \\
0.3048 & $\mathrm{ft}$ & $\mathrm{m}$ & 3.2808 \\
3.7854 & gal & $\mathrm{L}$ & 0.2642 \\
2.54 & inch $(\mathrm{es})$ & $\mathrm{cm}$ & 0.3937 \\
25.4 & inch $(\mathrm{es})$ & $\mathrm{mm}$ & 0.0394 \\
1.1209 & lb/acre & $\mathrm{kg} \cdot \mathrm{ha}^{-1}$ & 0.8922 \\
1 & meq/100 g & $\mathrm{cmol} \cdot \mathrm{kg}^{-1}$ & 1 \\
0.0254 & mil & $\mathrm{mm}$ & 39.3701 \\
28.3495 & $\mathrm{oz}$ & $\mathrm{g}$ & 0.0353 \\
1 & $\mathrm{ppm}$ & $\mathrm{mg} \cdot \mathrm{dm}^{-3}$ & 1 \\
1 & $\mathrm{ppm}$ & $\mathrm{mg} \cdot \mathrm{kg}^{-1}$ & 1 \\
2.2417 & ton $(\mathrm{s}) / \mathrm{acre}$ & $\mathrm{Mg} \cdot \mathrm{ha}^{-1}$ & 0.4461 \\
$\left({ }^{\circ} \mathrm{F}-32\right) \div 1.8$ & ${ }^{\circ} \mathrm{F}$ & ${ }^{\circ} \mathrm{C}$ & $\left({ }^{\circ} \mathrm{C} \times 1.8\right)+32$ \\
& & & \\
\hline
\end{tabular}


numerous benefits, including increased nitrogen fertility, retention of nutrients, reduced erosion and runoff, improved soil physical properties, building soil organic matter, suppressions of pest populations, and weed control (Creamer and Baldwin, 2000; Snapp et al., 2005), they are underused in strawberry production. Moreover in NC, growers often replant strawberry crops on the same site, leaving inadequate time for an intervening cash crop, and while summer cover crops are recommended (Poling et al., 2005), they are not commonly implemented. Although planting a summer cover crop between the final harvest in mid-June and soil preparation starting early September is feasible in NC, this may not provide adequate time to maximize cover crop biomass and subsequent yield benefits to strawberry plants. Garland et al. (2011) suggested summer cover crop growth in NC strawberry production may be enhanced through increased seeding rate and compost additions when cover crops are planted; yet, research is lacking to provide growers any practical recommendations.

Although compost and cover crops may improve soil quality in strawberry agroecosystems, adding vermicompost provides an opportunity to augment the soil ecosystem with an array of beneficial organisms that are

This paper forms part of the thesis submitted by John E. Beck in fulfilling a MS degree requirement at North Carolina State University.

This research was supported by the Southern Region Small Fruit Consortium.

We are thankful to the Center for Environmental Farming Systems for providing the research plot and field staff, especially Ken Fager, Dolly Watson, Consuelo Arellano, Absalom Heatwole Shank, Miranda Ganci, and Sarah Seehaver. We are grateful to all editors and anonymous reviewers for their valuable suggestions on the manuscript.

Mention of a trademark, proprietary product, or vendor does not constitute a guarantee or warranty of the product and does not imply its approval to the exclusion of other products or vendors that also may be suitable.

${ }^{1}$ Cooperative Extension Program, North Carolina Agricultural and Technical State University, Greensboro, NC 27411

${ }^{2}$ Department of Crop Science, North Carolina State University, Campus Box 7620, Raleigh, NC 27695

${ }^{3}$ Department of Horticultural Science, North Carolina State University, Campus Box 7609, Raleigh, NC 27695

${ }^{4}$ Department of Horticultural Science, University of Minnesota, Saint Paul, MN 55108

${ }^{5}$ Corresponding author. E-mail: michelle_schroeder@ ncsu.edu.

doi: 10.21273/HORTTECH03447-16 often eliminated through chemical fumigation (Werner et al., 1990) and even biofumigation practices (Owen et al., 2010). Vermicompost is the stabilized product of the interaction between earthworms and soil microorganisms in a nonthermophilic process, resulting in a material with high porosity, aeration, drainage, waterholding capacity, and microbial activity (Arancon et al., 2006; Singh et al., 2008). Vermicompost applications to strawberry crops can enhance microbial populations, including bacteria, fungi, and actinomycetes (Arancon et al., 2004). Several studies have demonstrated vermicompost can improve strawberry growth, including leaf area, shoot biomass, number of flowers and runners (Arancon et al., 2004), and yield (Arancon et al., 2004; Singh et al., 2008), although the mechanisms for this are unclear. Moreover, vermicompost applications to strawberry have increased microbial biomass N (Arancon et al., 2006) and protected fruit marketability through reduction in physiological disorders and fruit disease, such as botrytis rot [Botrytis cinerea (Singh et al., 2008)] Well-designed cover crop rotations that increase soil organic matter along with vermicompost applications may help reduce fertilizer applications while also improving the belowground environment for the soil microbial community; yet, little is understood concerning the potential interactions of these practices in strawberry production.

The primary objective of this study was to examine the effects of six summer cover crop treatments including pearl millet, soybean, cowpea, pearl millet/soybean combination, pearl millet/cowpea combination, and a no cover crop control, vermicompost additions, and their interactions on strawberry growth and yields in a 2-year field study in NC. The cover crop species and combinations examined in this study were previously found to be easily integrated into $\mathrm{NC}$ strawberry production (Garland et al., 2011). Compost was additionally added at cover crop seeding to augment cover crop growth and reduce preplant fertility. An additional objective of this study examined the effects of these treatments on available soil $\mathrm{N}$ throughout the strawberry season. We hypothesize that cover crops (with composts) and vermicompost would increase strawberry growth and yields and cover crop treatments, primarily those with legumes, would increase soil $\mathrm{N}$ during strawberry production. This study has implications for organic strawberry production, those in transition to organic production, as well as practices for conventionally managed strawberry production in NC and in the SE regions with similar soil, climatic, and pest conditions.

\section{Materials and methods}

Experimental Design. A 2 -year field experiment was conducted at the Center for Environmental Farming Systems in Goldsboro, NC (lat. $35^{\circ} 22^{\prime} 14^{\prime \prime} \mathrm{N}$, long. $78^{\circ} 2^{\prime} 53^{\prime \prime} \mathrm{W}$ ) from June 2009 to June 2011. For 2 years prior, the site was managed in a conventional corn:soybean:oat rotation and had not previously been in strawberry production, nor fumigated. The field experiment was a split-plot model based on a randomized complete block design with six replications. The whole-plot treatments were randomized and consisted of six cover crop treatments and subplots consisted of two vermicompost treatments. Strawberry production management followed USDA National Organic Program guidelines for fertility, pest management, and nonfumigation practices, with the exceptions that the land was not organic certified, nor were the strawberry plugs certified organic. The soil type was a Lynchburg fine sandy loam (fine-loamy, siliceous, semiactive, thermic Aeric Paleaquult).

The six summer cover crop treatments consisted of one grass grown alone: 1) 'Tifleaf 3' pearl millet [PM (Kaufman Seed Co., Ashdown, AR)]; two legumes grown alone: 2 ) 'Laredo' soybean [SB (Kaufman Seed Co.)] and 3) 'Iron Clay' cowpea [CP (Wyatt Quarles Seed Co., Garner, NC)]; two grass/legume combinations: 4) pearl millet/soybean (PMSB) and 5) pearl millet/cowpea (PMCP); and 6) no cover crop (NOCC). With the exception of the NOCC treatment (6), all cover crop treatments (1-5) received a compost application before cover crop planting. Throughout this study, cover crop treatments (1-5) were integrated with compost applications and therefore the effects of these are not separated. The vermicompost treatment consisted of either applications of vermicompost [VERM (Vermicycle Organics, Wilson, NC)] or no 
vermicompost (NO VERM). Compost and vermicompost were analyzed for $\mathrm{N}$, phosphorus $(\mathrm{P})$, and potassium (K) contributions before applications.

Cover crop treatments were randomized into six replicated blocks, each consisting of six $20 \times 40$-ft plots for a total of 36 plots. Each cover crop main plot was split into two 3 -ft-wide by 14 -ft-long raised beds for planting strawberry plants with or without or vermicompost applications. Vermicompost treatment beds within plots were spaced $8 \mathrm{ft}$ apart from center, wider than typical production (typically $5 \mathrm{ft}$ center to center) to prevent any potential treatment contamination effects. Strawberry plugs were planted in two rows at $\approx 12$ inches between plant spacing to fit 26 strawberry plants per split plot and 52 plants per cover crop plot. The location of cover crop and vermicompost treatments were conserved in the same location each year.

Field MANAGEMENT. Before cover crop planting, compost (McGill $A G$ compost consisting of 3 organic matter : 1 class A biosolids and preconsumer food waste; McGill Environmental Systems, Rose Hill, NC) was applied at 11 tons/acre on 18 June $2009(2.5 \mathrm{~N}-$ $0.4 \mathrm{P}-1.2 \mathrm{~K}$ ) and 13.8 tons/acre on 24 June $2010(2.6 \mathrm{~N}-0.4 \mathrm{P}-1 \mathrm{~K})$ to cover crop treatment (1-5) plots using a litter spreader (Chandler Equipment Co., Gainesville, GA) and incorporated with a disk. Compost rates were comparable to rates applied in organic strawberry production (Reganold et al., 2010). All no cover crop plots were covered with plastic sheeting during compost application to ensure they did not receive compost.

Cover crops were planted 24 June 2009 and 2 July 2010 using a grain drill (2055 No-till Grain Drill; Sukup Manufacturing Co., Sheffield, IA). SB seeds were inoculated in 2009 and 2010 with Bradyrhizobium japonicum (INTX Microbials, Kentland, IN) and CP seeds were inoculated with Bradyrbizobium sp. in 2009 and 2010 (INTX Microbials). Cover crop treatments were planted using seeding rates previously described for strawberry production in NC (Garland et al., 2011), which includes increased legume seeding rates to maximize production in a short time frame when grown with a grass. In Year 1 (2009-10) and Year 2 (201011), cover crops were seeded at the following rates: $\mathrm{PM}$ at $30 \mathrm{lb} / \mathrm{acre}, \mathrm{SB}$ at $120 \mathrm{lb} /$ acre, $C P$ at $100 \mathrm{lb} /$ acre, $\mathrm{PM}$ at $10 \mathrm{lb} / \mathrm{acre}$, and $\mathrm{SB}$ at $120 \mathrm{lb} /$ acre in PMSB combination, and PM at $10 \mathrm{lb} /$ acre and $\mathrm{CP}$ at $100 \mathrm{lb} /$ acre in PMCP combination. A 12 -ft-wide 'Piper' sudangrass [Sorghum bicolor (Kaufman Seed Co.)] buffer was planted between blocks and around the field perimeter. Irrigation was not used on cover crops. Precipitation was monitored using data from the North Carolina State Climate Office and average daily measurements were above the 30-year normals for Goldsboro, $\mathrm{NC}$, in both years. After 9 weeks of growth (29 Aug. 2009, 3 Sept. 2010), cover crops were flail mowed and incorporated with a disk. No treatment plots were fumigated.

In addition to compost and cover crops, strawberry preplant fertilizers consisting of soybean meal and sodium borate, were applied to all plots 1 week after cover crop biomass incorporation each year. Cover crop treatments $(1-5)$ were fertilized with $20 \mathrm{lb} /$ acre of $\mathrm{N}$ derived from soybean meal $7 \mathrm{~N}-0.4 \mathrm{P}-$ $0.8 \mathrm{~K}$ (Nahunta Feed Supply, Pikeville, $\mathrm{NC}$ ), representing $33 \%$ of the recommended rate for strawberry production in the SE (Dycus, 2011; Poling et al., 2005) to account for $\mathrm{N}$ fertility added from the compost and cover crops. NOCC plots (6) received the full recommended rate of $60 \mathrm{lb} /$ acre of $\mathrm{N}$ also derived from soybean meal. Soybean meal was broadcasted using a drop spreader (model 1006; Gandy Co., Owatonna, MN) and disked in. Sodium borate spray (Crop Production Services, Princeton, NC) was applied to all plots with an eight-row sprayer at $1.0 \mathrm{lb} /$ acre. Strawberry plasticulture beds were formed with a bed shaper and plastic mulch layer (Kennco Manufacturing, Ruskin, FL) using embossed 1.25 -mil black plastic mulch and 10 -mil drip tape $(0.4 \mathrm{gal} / \mathrm{min}, 12$-inch spacing).

STRAWBERry MANAGEMENT. Although certified organic strawberry tips were purchased each year to develop plugs inoculated with vermicompost, problems with phytophthora (Phytophthora cactorum) in Year 1 and water stress due to high heat and inadequate moisture in the greenhouse in Year 2 prevented these organic plugs from being used in the study. Conventionally produced 'Camarosa' (2009) and 'Chandler' (2010) strawberry plugs were purchased from local growers and planted on 16 Oct. 2009 and 19 Oct. 2010. The vermicompost treatment (VERM) was modified therefore to be added at the time of planting each year. VERM treatment split plots received 1 tablespoon $(8 \mathrm{~g})$ of swine manure-based Vermicycle Worm Castings $[2.1 \mathrm{~N}-1 \mathrm{P}-0.8 \mathrm{~K}$ (Vermicycle Organics)] mixed into each strawberry planting hole. This was the equivalent amount of vermicompost recommended per plant in a plug potting volume (15\%).

Yield data were collected from the center 12 plants and all plants were harvested on collection days. Five of the buffer plants were randomly selected and marked for biomass collection. Beginning 18 Mar. 2010 and 15 Mar. 2011, all plots received $48 \mathrm{lb} /$ acre $\mathrm{K}$ and $24 \mathrm{lb} /$ acre $\mathrm{N}$ through drip irrigation divided in weekly equivalents over a 4-week period. Soluble fertilizers were derived from Organic Materials Review Institute (OMRI)-approved ALLGANIC potassium sulfate [ $0 \mathrm{~N}-$ 0P-43.2K (SQM Organic, Atlanta, GA)] and ALLGANIC sodium nitrate $[16 \mathrm{~N}-0 \mathrm{P}-0 \mathrm{~K}+$ minerals $(\mathrm{SQM}$ Organic)], with sodium nitrate applied as $20 \%$ of the total $\mathrm{N}$ budget in accordance with the USDA National Organic Program Rule. In 2011, the final week's supply of $\mathrm{N}$ (6 lb/acre) was replaced with all natural Verde Growth Enhancer [16N-0.4P-1.7K (Humboldt Nutrients, Eureka, CA)] when OMRI-approved soluble fertilizers were lacking in local markets.

Data collection. Soil fertility was analyzed from 10 composited soil samples collected at 6 inches from each plot in June 2009, Oct. 2009, Oct. 2010, and June 2011. The NC Department of Agriculture \& Consumer Services Agronomic Services Division (NCDA\&CS, Raleigh, NC) analyzed all soil, compost, vermicompost, and plant tissue samples. Aboveground cover crop biomass were collected from two randomly placed $28 \times 28$-inch quadrats in each plot 9 weeks after planting in 2009 and 2010 , and were assessed for biomass and nutrient content. All cover crop biomass within each quadrat was removed, dried at $60^{\circ} \mathrm{C}$ for $5 \mathrm{~d}$, weighed, and ground using a sample mill (Cyclotec 1093; FOSS, Hillerød, Denmark). Individual species in mixed cover crop treatments were separated and analyzed independently. Cover crops were 
analyzed for concentrations of $\mathrm{N}, \mathrm{P}, \mathrm{K}$, calcium (Ca), magnesium $(\mathrm{Mg})$, sulfur $(\mathrm{S})$, iron $(\mathrm{Fe})$, manganese $(\mathrm{Mn})$, zinc $(\mathrm{Zn})$, copper $(\mathrm{Cu})$, boron $(\mathrm{B})$, and sodium (Na). All aboveground weed biomasses were harvested from three randomly placed $20 \times 20$-inch quadrats from each plot at cover crop harvest, dried, and weighed similar to cover crops.

One strawberry plant was collected per subplot treatment bed at planting and six times during each growing season: 16 Oct., 28 Dec., 21 Feb., 5 Apr., 3 May, and 31 May for the 2009-10 season (Year 1), and 19 Oct., 3 Jan., 7 Mar., 7 Apr., 11 May, and 31 May for the 2010-11 season (Year 2). Sampling dates were chosen to correspond with phenological stages of dormancy, spring growth, peak flowering, peak fruiting, and final harvest. Plants were removed from the field by digging a $12 \times 12$-inch area around each plant, carefully shaking the soil from the roots and then gently rinsing with water. Plants were separated to roots, crowns, leaves, petioles, flowers, and fruit; dried at $60{ }^{\circ} \mathrm{C}$ for a minimum of $72 \mathrm{~h}$; and weighed. Strawberry fruit yield was collected every Monday and Thursday beginning on 22 Apr. 2010 and continued for 4.5 weeks. The process was repeated in Year 2 beginning on 14 Apr. 2011 lasting for 6 weeks.

INORGANIC NITRATE-NITROGEN $\left(\mathrm{NO}_{3}-\mathrm{N}\right)$ AND AMMONIUM-NITROGEN $\left(\mathrm{NH}_{4}-\mathbf{N}\right)$ soIL ANALYSIS. Soil samples were collected from the root zones of strawberry plants in each of the 72 split plots at five times during Year 1 and six times during Year 2. These sampling dates correspond with strawberry plant biomass collection dates, with the exception of the second through fifth sample dates in Year 1, which were taken $1 \mathrm{~d}$ after biomass collection. Six soil cores per split plot were randomly collected from the root zone between treatment plants at $\approx 15-\mathrm{cm}$ depth and composited. All soil samples from Year 1 and the first two sets from Year 2 were fumigated with methyl bromide in accordance with NCDA\&CS noxious weed quarantine procedures. Beginning 1 Feb. 2011, NCDA\&CS eliminated methyl bromide fumigation protocols for soil samples, therefore the Mar., Apr., and May 2011 soil samples were not fumigated. Samples were returned to North Carolina State University (NCSU) and dried at $45^{\circ} \mathrm{C}$ for $72 \mathrm{~h}$, ground to pass a 2 -mm sieve, and then stored at room temperature.

Inorganic $\mathrm{NO}_{3}-\mathrm{N}$ and $\mathrm{NH}_{4}-\mathrm{N}$ were extracted from soil samples following procedures modified from Keeney and Nelson (1982). An 8-g subsample was combined with $40 \mathrm{~mL}$ of $1 \mathrm{M}$ potassium chloride $(\mathrm{KCl})$ solution in an acid-washed specimen cup and agitated for $1 \mathrm{~h}$. Blank samples consisting of $1 \mathrm{M} \mathrm{KCl}$ solution were included to account for any $\mathrm{N}$ present in the filter paper. Shaken samples settled for $20 \mathrm{~min}$ and were filtered through quantitative filter paper (Fischer Scientific, Waltham, MA) and decanted into $20-\mathrm{mL}$ vials and frozen. Thawed samples were analyzed for $\mathrm{NO}_{3}-\mathrm{N}$ and $\mathrm{NH}_{4}-\mathrm{N}$ on a flow injection analyzer (Lachat Quik-Chem 8000; Hach Co., Loveland, CO). The results were corrected by subtracting the inorganic $\mathrm{N}$ levels returned from blank samples and then multiplied by the extractant:soil mass ratio $(5: 1)$. Final results are reported in milligrams $\mathrm{N}$ per kilogram.

Statistical ANALYsis. Data were analyzed separately by year (Year $1=$ 2009-10; Year 2 = 2010-11) because of cultivar differences according to the split-plot model using PROC MIXED in SAS (version 9.2; SAS Institute, Cary, NC) with the fixed effects as cover crop, vermicompost, and their interactions. Statistical significance was expressed at the $P \leq 0.05$ level based on Type III sums of squares. Pairwise mean comparisons were performed on all significant effects using Tukey's honest significant difference test at $P \leq 0.05$. Analysis of data taken outside of strawberry season (cover crop biomass, weeds, and soil variables) did not include vermicompost effects. Data taken during strawberry season (strawberry yield, biomass, plant nutrients, and soil extractable N) were analyzed separately following the split-plot design for each sample date. Two-way multivariate analysis of variance was used to analyze soil nutrients, leaf/ petiole nutrients, strawberry yield (total yield, marketable yield, cull yield, and average berry weight), and biomass (roots, crowns, leaves, flowers, and fruit) data since these data can be interrelated. Subsequent two-way analysis of variance results are presented for each response variable.

\section{Results}

Cover Crops. Cover crop treatments produced different amounts of aboveground dry weights at harvest $[P<0.001$ (Fig. 1A)] both years. In Year 1, treatments that included PM (individually or in combination) produced greater dry weights than those with legumes (CP, SB) alone $(P \leq$ 0.05 ). In Year 2, PM produced more dry weights than all other treatments, whereas SB produced less dry weights than all other treatments $[P \leq 0.05$ (Fig. 1A)]. Macronutrient concentrations $(\mathrm{N}, \mathrm{P}, \mathrm{K}, \mathrm{Mg}, \mathrm{S})$ were greatest in PMCP and PMSB shoot tissues in both years (Table 1). Cover crop $\mathrm{N}$ concentrations and dry weights at harvest resulted in an estimation of total organic $\mathrm{N}$ applied as follows: Year 1-PM $116 \mathrm{lb} /$ acre, SB 132 lb/acre, CP $155 \mathrm{lb} /$ acre, PMCP $347 \mathrm{lb} / \mathrm{acre}$, and PMSB $439 \mathrm{lb} /$ acre; Year 2-PM $131 \mathrm{lb} /$ acre, SB $19 \mathrm{lb} /$ acre, CP $98 \mathrm{lb} /$ acre, PMCP $266 \mathrm{lb} /$ acre, and PMSB $261 \mathrm{lb} /$ acre.

All cover crop treatments had less weed dry weights than the no cover crop treatment in Year $1(P<$ $0.001)$, whereas the no cover crop treatment had similar amounts of weed dry weights to all other cover crop treatments except PM in Year 2 $[P<0.001$ (Fig. 1B)]. No weeds were collected from sample quadrats in the PMCP treatments in Year 1 and the PM treatment in Years 1 and $2[P<$ 0.05 (Fig. 1B)].

\section{STRAWBERRY YIELD AND BIOMASS.} Although cover crops and vermicompost treatments did not impact any strawberry yield response (total, marketable, cull yields, or average berry weights) in Year 1, vermicompost increased total and marketable yields in Year 2 (Table 2). In Year 2, PM decreased total and marketable yields compared with the NOCC treatment but did not differ from SB total and marketable yields (Table 2). Neither cover crop nor vermicompost treatments affected cull or average fruit weights in both years, and no interactions between cover crop and vermicompost were observed for any yield analysis.

Similar to yields, neither cover crop nor vermicompost treatments affected any strawberry dry weight responses at any sample dates in Year 1 , but cover crops [Wilks' $\lambda=0.132$, $F(20,76.16)=3.11, P<0.001]$ and vermicompost [Wilks' $\lambda=0.958, F(4$, $237)=2.56, P=0.039]$ did impact strawberry dry weights in Year 2 (Table 3). In Year 2, PM decreased 


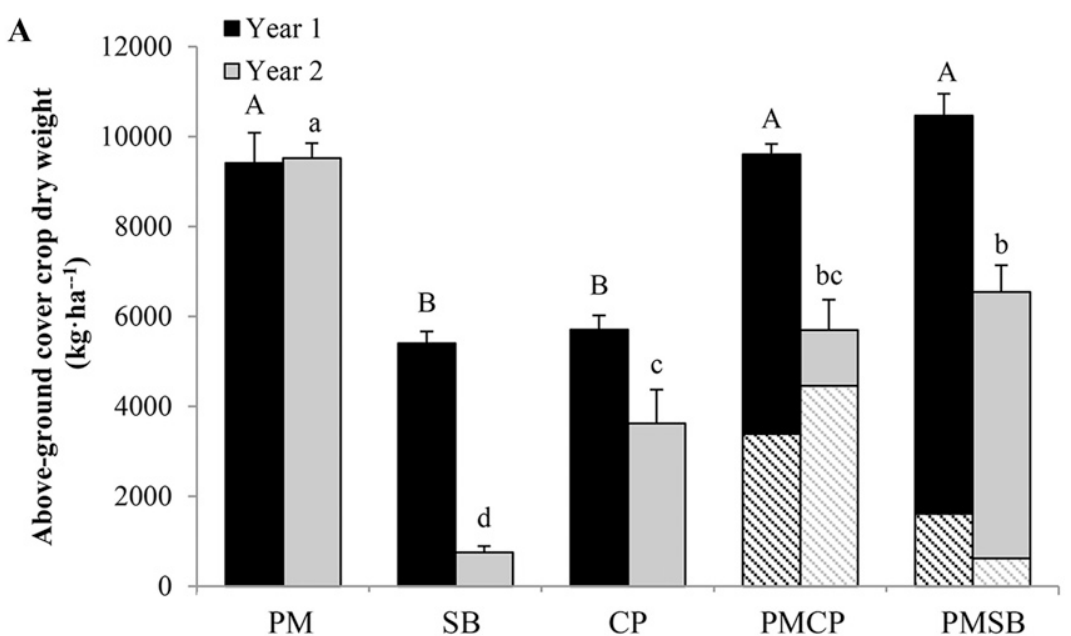

Cover crop

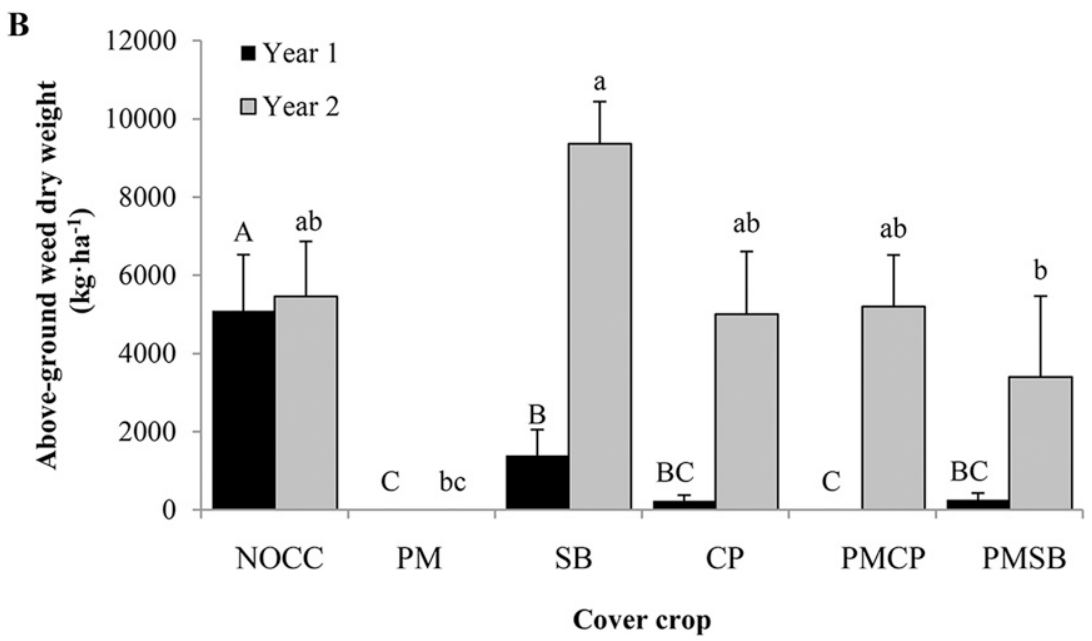

Fig. 1. Mean aboveground cover crop (A) and weed (B) dry weights from cover crop plots sampled 9 weeks after planting in Year 1 (2009-10) and Year 2 (201011). Cover crop treatments include no cover crop (NOCC), pearl millet (PM), soybean (SB), cowpea (CP), pearl millet + soybean combination (PMSB), and pearl millet + cowpea combination (PMCP). Hatched areas in the combination treatments represent the legume $(S B$ or $C P)$ fraction. Error bars indicate $+S E$ and bars with the same letter are not significantly different according to Tukey's honest significant difference test at $P \leq 0.05$. Each year was analyzed separately using oneway analysis of variance (ANOVA). Capitalization of letters refers to separate year analysis; $1 \mathrm{~kg} \cdot \mathrm{ha}^{-1}=0.8922 \mathrm{lb} /$ acre.

strawberry root weights compared NOCC treatments on 7 Jan. $(P=$ 0.013 ), decreased crown weights compared with NOCC and PMCP treatments on 7 Mar. $(P=0.004)$, decreased flower and fruit weights compared with PMCP and PMSB treatments on 7 Mar. $(P=0.029)$, and decreased flower and fruit weights compared with all treatments on 7 Apr. $[P=0.004$ (data not shown)]. Since vermicompost treatments did not affect any dry weight responses in Year 1, only Year 2 results are presented (Table 3). In Year
2, VERM treatments increased root weights on 11 May $(P=0.030)$, increased crown weights on 7 Mar. $(P=0.002)$, increased flower and fruit weights on 7 Mar. $(P=0.046)$ and 11 May $(P=0.004)$, and increased leaf and petiole weights on 7 Mar. $(P=$ $0.002)$ and 11 May $(P=0.031)$ compared with NO VERM treatments (Table 3).

SoIL NUTRIENTs. Cover crops increased mean differences in $\mathrm{Ca}, \mathrm{P}, \mathrm{Zn}$, base saturation $(\mathrm{BS} \%), \mathrm{pH}$, and cation exchange capacity (CEC) between the baseline (10 June 2009) and final
(31 May 2011) soil analysis compared with NOCC treatments (Table 4). Negative K values indicated an overall decline in $\mathrm{K}$ among all treatments over 2 years, but to a lesser degree among PM and PM in combination with either CP or SB. VERM treatments increased mean soil differences in $\mathrm{Ca}, \mathrm{Cu}, \mathrm{K}, \mathrm{Zn}, \mathrm{BS} \%, \mathrm{CEC}$, and $\mathrm{pH}$ compared with the NO VERM treatments (Table 4). No interactions between cover crop and vermicompost were observed for any soil nutrient analysis.

INORGANIC $\mathrm{NO}_{3}-\mathrm{N}$ AND $\mathrm{NH}_{4}-$ N. In Year 1, NOCC treatments had less soil extractable $\mathrm{NH}_{4}-\mathrm{N}$ than the $\mathrm{CP}$ and PMSB treatments on $22 \mathrm{Feb}$. [Tukey-Kramer $P<0.05$ (Fig. 2A)], and less than the SB treatment on 4 May [Tukey-Kramer $P<0.05$ (Fig. 2A)], whereas PMCP treatments had greater extractable $\mathrm{NO}_{3}-\mathrm{N}$ than the NOCC and PM treatments on 29 Dec. [Tukey-Kramer $P<0.05$ (Fig. 2B)], greater than NOCC and CP on 22 Feb. [Tukey-Kramer $P<0.05$ (Fig. 2B)], and greater than the SB treatment on 31 May [Tukey-Kramer $P<0.05$ (Fig. 2B)]. In Year 2, NOCC treatments had less extractable soil $\mathrm{NH}_{4}-\mathrm{N}$ values than $\mathrm{PM}, \mathrm{SB}, \mathrm{CP}$, and PMSB treatments on 11 May [Tukey-Kramer $P<0.05$ (Fig. 2C)]. In Year 2, extractable soil $\mathrm{NO}_{3}-\mathrm{N}$ values were lower for NOCC and PM treatments than PMCP on 3 Jan. [Tukey-Kramer $P<0.05$ (Fig. 2D)], NOCC lower than PM and PMCP treatments on 11 May [Tukey-Kramer $P<0.05$ (Fig. 2D)], and NOCC treatments were lower compared with PM, SB, and PMCP treatments on 31 May [Tukey-Kramer $P<0.05$ (Fig. 2D)]. Neither effects of vermicompost treatments, nor any interactions between cover crop and vermicompost were detected, thus these data are not shown.

\section{Discussion}

Although composts, cover crops, and vermicompost additions can be important sustainable practices that enhance soil organic matter, soil microbial communities, and available $\mathrm{N}$ in conventional strawberry production and practical strategies for transition to organic production, not all of these practices always enhance strawberry yields as found in this study. In our study, even small vermicompost additions $(8 \mathrm{~g})$ at planting increased 
Table 1. Mean nutrient concentrations of cover crop shoot dry weights 9 weeks after planting in Year 1 (2009) and Year 2 (2010). Nitrogen $(N)$, phosphorus $(P)$, potassium $(K)$, calcium $(C a)$, magnesium $(\mathrm{Mg})$, and sulfur $(S)$ data shown as percent and iron $(\mathrm{Fe})$, manganese $(\mathrm{Mn})$, zinc $(\mathrm{Zn})$, copper $(\mathrm{Cu})$, boron $(\mathrm{B})$, and sodium $(\mathrm{Na})$ shown as milligrams per kilogram.

\begin{tabular}{|c|c|c|c|c|c|c|c|c|c|c|c|c|}
\hline & $\mathbf{N}$ & $\mathbf{P}$ & $\mathbf{K}$ & $\mathrm{Ca}$ & $\mathrm{Mg}$ & $S$ & $\mathrm{Fe}$ & Mn & $\mathrm{Zn}$ & $\mathrm{Cu}$ & B & $\mathrm{Na}$ \\
\hline & \multicolumn{6}{|c|}{$(\%)$} & \multicolumn{6}{|c|}{$\left(\mathrm{mg} \cdot \mathrm{kg}^{-1}\right)^{\mathrm{z}}$} \\
\hline \multicolumn{13}{|c|}{ Year 1} \\
\hline SB & $2.75 \mathrm{~b}$ & $0.33 \mathrm{c}$ & $2.47 \mathrm{c}$ & $0.78 \mathrm{~b}$ & $0.29 \mathrm{~b}$ & $0.24 \mathrm{~b}$ & $179 \mathrm{ab}$ & $41 \mathrm{~b}$ & $33 \mathrm{~b}$ & $21 \mathrm{ab}$ & $31 \mathrm{~b}$ & $184 \mathrm{~b}$ \\
\hline $\mathrm{CP}$ & $3.05 \mathrm{~b}$ & $0.32 \mathrm{c}$ & $3.68 \mathrm{~b}$ & $1.21 \mathrm{a}$ & $0.30 \mathrm{~b}$ & $0.31 \mathrm{~b}$ & $64 c$ & 82 a & $49 \mathrm{~b}$ & $10 \mathrm{~b}$ & $31 \mathrm{~b}$ & $188 \mathrm{~b}$ \\
\hline PMCP & $4.05 \mathrm{a}$ & $0.86 \mathrm{a}$ & $6.95 \mathrm{a}$ & $1.52 \mathrm{a}$ & $0.56 \mathrm{a}$ & $0.66 \mathrm{a}$ & $123 \mathrm{~b}$ & $135 \mathrm{a}$ & $86 a$ & $21 \mathrm{a}$ & $35 \mathrm{ab}$ & 558 a \\
\hline \multicolumn{13}{|c|}{ Year 2} \\
\hline $\mathrm{PM}^{\mathrm{y}}$ & $1.54 c^{x}$ & $0.38 \mathrm{~b}$ & $3.19 \mathrm{c}$ & $0.38 \mathrm{~d}$ & $0.22 \mathrm{c}$ & $0.19 \mathrm{~d}$ & $72 \mathrm{~b}$ & $39 c$ & $31 \mathrm{~d}$ & $10 \mathrm{c}$ & $10 \mathrm{~d}$ & $150 \mathrm{~b}$ \\
\hline SB & $2.73 \mathrm{~b}$ & $0.36 \mathrm{~b}$ & $3.24 \mathrm{c}$ & $1.07 \mathrm{c}$ & $0.36 \mathrm{~b}$ & $0.27 \mathrm{c}$ & $232 \mathrm{a}$ & $39 c$ & $34 \mathrm{~cd}$ & $22 \mathrm{~b}$ & $39 \mathrm{~b}$ & $217 \mathrm{~b}$ \\
\hline $\mathrm{CP}$ & $3.04 \mathrm{~b}$ & $0.30 \mathrm{~b}$ & $4.44 \mathrm{~b}$ & $1.36 \mathrm{bc}$ & $0.39 \mathrm{~b}$ & $0.36 \mathrm{~b}$ & $146 \mathrm{ab}$ & $71 \mathrm{~b}$ & $40 \mathrm{c}$ & $14 \mathrm{c}$ & $35 \mathrm{c}$ & $217 \mathrm{~b}$ \\
\hline PMCP & $5.22 \mathrm{a}$ & $0.75 \mathrm{a}$ & $9.12 \mathrm{a}$ & $1.86 \mathrm{a}$ & $0.67 \mathrm{a}$ & $0.59 \mathrm{a}$ & $278 \mathrm{a}$ & $120 \mathrm{a}$ & $83 a$ & $27 \mathrm{ab}$ & $47 \mathrm{a}$ & $233 \mathrm{a}$ \\
\hline
\end{tabular}

${ }^{\mathrm{z}} 1 \mathrm{mg} \cdot \mathrm{kg}^{-1}=1 \mathrm{ppm}$

${ }^{y}$ Cover crop treatments: $\mathrm{PM}=$ pearl millet; $\mathrm{SB}=$ soybean; $\mathrm{CP}=$ cowpea; $\mathrm{PMSB}=$ pearl millet + soybean combination; $\mathrm{PMCP}=$ pearl millet + cowpea combination.

${ }^{x}$ Means within a column followed by the same letter were not significantly different according to Tukey's honest significant difference test at $P \leq 0.05$. Years were analyzed separately.

${ }^{\mathrm{w}_{\mathrm{NS}},{ }^{*}, * *}, * * *$ Nonsignificant or significant at $P \leq 0.05,0.01$, or 0.001 , respectively, based on a mixed-model analysis of variance test.

Table 2. Effects of cover crop and vermicompost treatments on strawberry fruit mean total yield, marketable yield, cull yield, and average fruit weight in Year 1 (2010) and Year 2 (2011).

\begin{tabular}{|c|c|c|c|c|c|c|c|c|}
\hline & \multirow{2}{*}{\multicolumn{2}{|c|}{$\frac{\text { Total yield }}{{\text { (g/plant })^{\mathrm{y}}}}$}} & \multirow{2}{*}{\multicolumn{2}{|c|}{$\begin{array}{c}\text { Marketable yield } \\
(\mathrm{g} / \text { plant })\end{array}$}} & \multirow{2}{*}{\multicolumn{2}{|c|}{$\begin{array}{c}\text { Culls } \\
\text { (g/plant })\end{array}$}} & \multirow{2}{*}{\multicolumn{2}{|c|}{$\frac{\text { Avg fruit wt }}{\text { (g/berry) }}$}} \\
\hline & & & & & & & & \\
\hline & Year 1 & Year 2 & Year 1 & Year 2 & Year 1 & Year 2 & Year 1 & Year 2 \\
\hline NOCC & 404 & $574 a^{x}$ & 356 & $479 \mathrm{a}$ & 48 & 95 & 14 & 21 \\
\hline PM & 412 & $433 \mathrm{~b}$ & 361 & $356 \mathrm{bc}$ & 51 & 78 & 14 & 20 \\
\hline SB & 408 & $497 \mathrm{ab}$ & 352 & 398 b & 56 & 99 & 14 & 20 \\
\hline PMSB & 443 & $525 \mathrm{a}$ & 392 & $428 \mathrm{ab}$ & 51 & 97 & 15 & 21 \\
\hline Significance $^{w}$ & NS & *** & NS & $* * *$ & NS & NS & NS & NS \\
\hline \multicolumn{9}{|c|}{ Vermicompost treatment ${ }^{\mathrm{v}}$} \\
\hline NO VERM & 409 & $502 \mathrm{~b}^{\mathrm{x}}$ & 357 & $408 \mathrm{~b}$ & 53 & 95 & 14 & 20 \\
\hline VERM & 424 & $546 \mathrm{a}$ & 372 & $445 \mathrm{a}$ & 53 & 101 & 14 & 20 \\
\hline
\end{tabular}

total and marketable strawberry yields but only in the 2 nd year. Strawberry yield enhancement from vermicomposts was not likely the result from the increased nutrients in the small amount of vermicompost material but more likely the impact of vermicompost on the soil microbial community and functioning that may have built up in the 2 nd year. Other studies have shown increased strawberry growth and yield with vermicompost additions that were not directly attributed to nutrient contents of vermicompost (Arancon et al., 2003, 2004; Singh et al., 2008). Several studies have postulated that plant growth regulators produced by the increased microbial biomass population of vermicompost may enhance plant growth and yield indirectly (Arancon et al., 2004, 2006; Singh et al., 2008). Arancon et al.
(2003) suggest that increases in plant growth may be due to the increased nutrient mineralization by microbial biomass populations where vermicompost is added. In addition, Singh et al. (2008) found that addition of vermicompost to strawberry plants resulted in fewer days to first flower and increased berry size and yields. In our study, vermicompost was added to individual plant root zones and not at 
Table 3. Mean per-plant dry weight of strawberry roots, crowns, petioles and leaves, and reproductive structures (fruit + flowers) for vermicompost (VERM) and no vermicompost (NO VERM) treatments in Year 2 (2010-11).

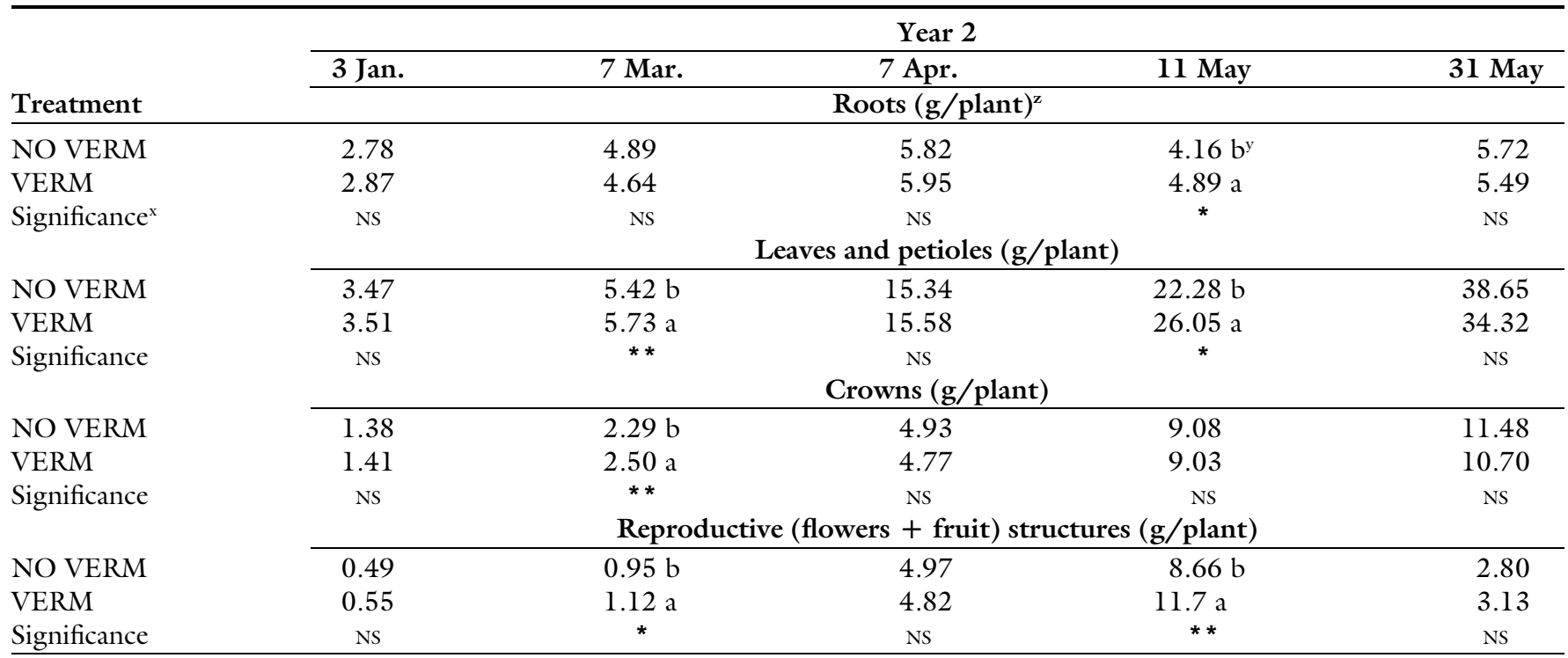

${ }^{\mathrm{z}} \mathrm{lg}=0.0353 \mathrm{oz}$.

${ }^{y}$ Means within a column followed by the same letter are not significantly different according to Tukey's honest significant difference test at $P \leq 0.05$.

${ }^{\mathrm{x}} \mathrm{NS},{ }^{*}, * *{ }^{* * *}$ Nonsignificant or significant at $P \leq 0.05,0.01$, or 0.001 , respectively, based on a mixed-model analysis of variance test.

larger field-scale applications as in other studies. Increasing the rate applied to the field or incorporating vermicompost during plug production may further enhance strawberry growth and yields, although additional research along with an economic analysis are warranted since vermicompost materials can be costly.

Although we found cover crop treatments (with compost additions) to have comparable strawberry yields to no cover crop treatments with $67 \%$ less preplant $\mathrm{N}$ fertilizer added, this was only in the first year. In the 2 nd year of the study, however, PM decreased total strawberry yields and PM and CP treatments decreased marketable yields compared with the NOCC controls. Although other studies have found yield benefits from summer cover crops in lettuce [Lactuca sativa (Isk et al., 2009)], spring muskmelon [Cucumis melo (Wang et al., 2008)], and 'Sanibel' tomato [Solanum lycopersicum (Wang et al., 2005)], specific cover crop species and combinations can have different impacts on the subsequent cash crop. These studies were conducted in hot and subtropical climates that lead to rapid residue decomposition, similar to conditions in eastern NC. Although PM produced the highest amount of cover crop biomass and eliminated weeds, it decreased strawberry yields in this study. These yield reductions may have been the result of either $\mathrm{N}$ immobilization or allelopathic effects of PM residues on strawberry plants. High biomassproducing cover crops with high carbon (C): $\mathrm{N}$ ratios, like PM, have been shown to immobilize available soil $\mathrm{N}$ at higher rates than legumes or mixed species (Sarr et al., 2008). Moreover, different cover crops can contain various amounts of allelopathic compounds and have the ability to reduce weed germination and growth when managed effectively (Weston, 1996). Cheema et al. (2013) found that allelopathy in PM inhibited summer weeds but also the succeeding wheat (Triticum aestivum) yield. Moreover, the same cover crop species will not perform exactly each year, and its biomass responses are the result of its abiotic and biotic interactions. Soybean aboveground biomass, for example in this study, was substantially reduced $(151 \%)$ from the first year to the 2 nd year, likely through competition with pigweed (Amaranthus sp.), which was particularly abundant in the soybean plots in the 2nd year. Before integrating any cover crop into a rotation, especially with a valuable cash crop such as strawberry, it is critical to understand the potential impacts of the specific cover crop or combination on the agroecosystem over time such as the impacts on weeds, allelopathy, soil N, soil organic matter, reduced erosion, and the overall budget in addition to just cash crop yields.

Composts and summer cover crops can add organic $\mathrm{N}$ sources that both organic and conventional strawberry growers can benefit from; however, it is difficult to predict how much $\mathrm{N}$ will be available to strawberry plants in the spring. Moreover, because composts were added with the cover crops in this study, it is impossible to separate out their individual effects. Although a common estimate is that $50 \%$ of added $\mathrm{N}$ from organic sources, in particular cover crops, will be available to subsequent crops (Creamer and Baldwin, 2000; Sarrantonio, 2007), this depends on a variety of factors including biomass produced, C:N content, mineralization rate, climate, and soil microbial populations (Bair et al., 2008). In this study, some cover crop treatments integrated with compost increased soil available $\mathrm{NH}_{4}-\mathrm{N}$ and $\mathrm{NO}_{3}-\mathrm{N}$ levels during the spring season when the strawberry demand for nutrients is high and soluble fertilizers for drip irrigation are expensive, especially those for organic production. This represents a $\mathrm{N}$ increase 6 to 9 months after cover crop incorporation. Although split $\mathrm{N}$ applications in the fall 
Table 4. Effect of cover crop and vermicompost treatments on mean differences between the baseline soil analysis before planting cover crops in Year 1 (2009-10) and final soil analysis after strawberry harvest in Year 2 (2010-11). Calcium (Ca), copper $(\mathrm{Cu})$, potassium $(\mathrm{K})$, magnesium $(\mathrm{Mg})$, phosphorus $(\mathrm{P})$, sulfur $(\mathrm{S})$, and zinc $(\mathrm{Zn})$ shown as milligrams per cubic decimeter, cation exchange capacity (CEC) shown as milliequivalents per $100 \mathrm{~g}$ of soil, and base saturation (BS\%) shown as percentage of CEC occupied by base cations.

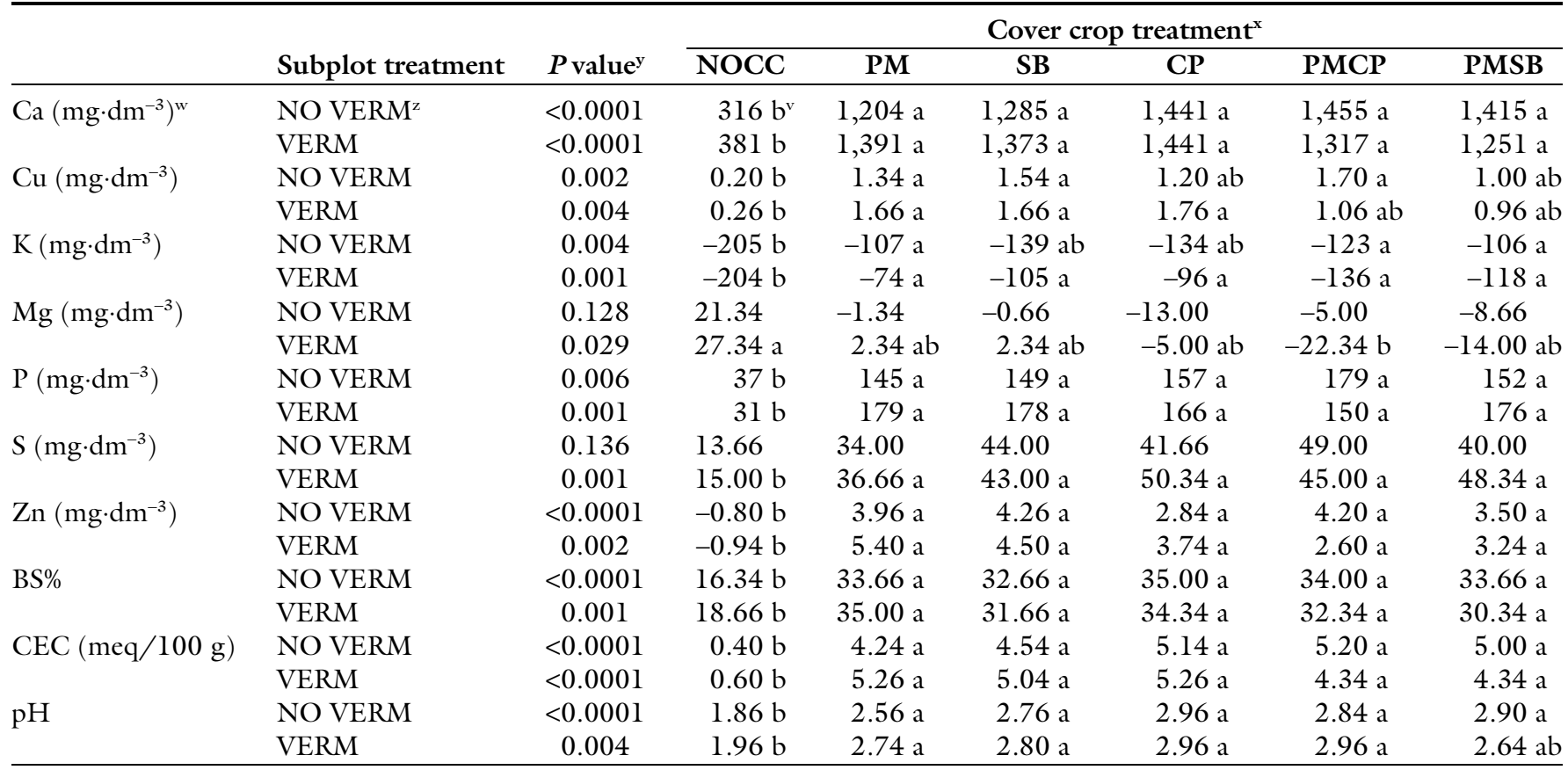

${ }^{2}$ NO VERM = no vermicompost; VERM = vermicompost.

yeported probability values are from two-way analysis of variance (ANOVA), bold indicates significance at $P \leq 0.05$.

${ }^{\mathrm{x}}$ Cover crop treatments: $\mathrm{NOCC}=$ no cover crop; $\mathrm{PM}=$ pearl millet $\mathrm{SB}=$ soybean; $\mathrm{CP}=$ cowpea PMSB $=$ pearl millet + soybean combination; $\mathrm{PMCP}=$ pearl millet + cowpea combination.

${ }^{\mathrm{w}} 1 \mathrm{mg} \cdot \mathrm{dm}^{-3}=1 \mathrm{ppm} ; 1 \mathrm{meq} / 100 \mathrm{~g}=1 \mathrm{cmol} \cdot \mathrm{kg}^{-1}$.

${ }^{\mathrm{N}}$ Means within rows for each soil nutrient followed by the same letter are not significantly different according to Tukey's honest significant difference test at $P \leq 0.05$.

(60 lb/acre) and spring (60-80 lb/ acre) are recommended to strawberry growers in the SE (Dycus, 2011; Poling et al., 2005), these are based on synthetic fertilizers and do not account for $\mathrm{N}$ credits from cover crop or compost additions. Using cover crops and composts together with the current recommended fertilizer rates for strawberry production therefore may exceed $\mathrm{N}$ needs, and subsequently, may even cause environmental challenges. In addition, cover crops together with composts increased other soil nutrients and characteristics (Ca, $\mathrm{P}, \mathrm{Zn}, \mathrm{BS} \%, \mathrm{pH}$, and $\mathrm{CEC}$ ) when compared with the no cover crop plots. Since benefits of additional organic matter are cumulative, effects from cover crops that build both soil organic matter and nutrient reserves are not always observed the first few years, and may take $4-5$ years to realize yield increases (Wang et al., 2009), despite not affecting yields in this study.

On various dates, the combination of PM and legume (either CP or SB) cover crop treatments produced the highest available soil $\mathrm{NH}_{4}-\mathrm{N}$ and
$\mathrm{NO}_{3}-\mathrm{N}$ levels over both years of the study. Moreover, these grass-legume combinations also produced the greatest total cover crop biomass in addition to PM alone in the first year of this study. Combining legume and grass cover crops can benefit strawberry growers due to the combined effects of their chemical structures. High Ncontent legumes residues, such as $\mathrm{SB}$ and $\mathrm{CP}$, will release a flush of $\mathrm{N}$ into the soil within a week of incorporation, and most $\mathrm{N}$ is mineralized within 6-8 weeks (Gaskell et al., 2009). More lignified, high C:N grasses, such as PM, can immobilize $\mathrm{N}$ and decompose more slowly, as $\mathrm{N}$ is gradually released (Sarrantonio, 2007) and becomes available later in the season (during flowering and fruiting) when fertilizer applications can be more difficult and expensive. In our study, PM also had the greatest cover crop biomass in the 2 nd year, yet lowest total $\mathrm{N}$ content and strawberry yields, suggesting that the amount of $\mathrm{N}$ released in the strawberry growing season may not have met plant demand in the spring.
Combining high C:N grass species and legume species with lower $\mathrm{C}: \mathrm{N}$ ratios may slow the early-season mineralization rate to meet subsequent crop demand (Giller and Cadisch, 1995). This strategy together with compost applications can supply organic $\mathrm{N}$ inputs, but long-term research is needed to quantify how this may impact synthetic $\mathrm{N}$ fertilizer recommendations in strawberry production in NC and beyond. This can be particularly important in organic strawberry production, where organic certified soluble fertilizers can be challenging to obtain and have a much greater cost per unit $\mathrm{N}$ compared with conventional fertilizers (Gaskell et al., 2009).

This study was the first to investigate the effects of cover crops (integrated with composts) and vermicompost additions in strawberry production. This approach is an initial step in developing sustainable soil management strategies for current organic strawberry producers and those interested in transitioning to organic certification in $\mathrm{NC}$ and the $\mathrm{SE}$ with similar conditions. More 


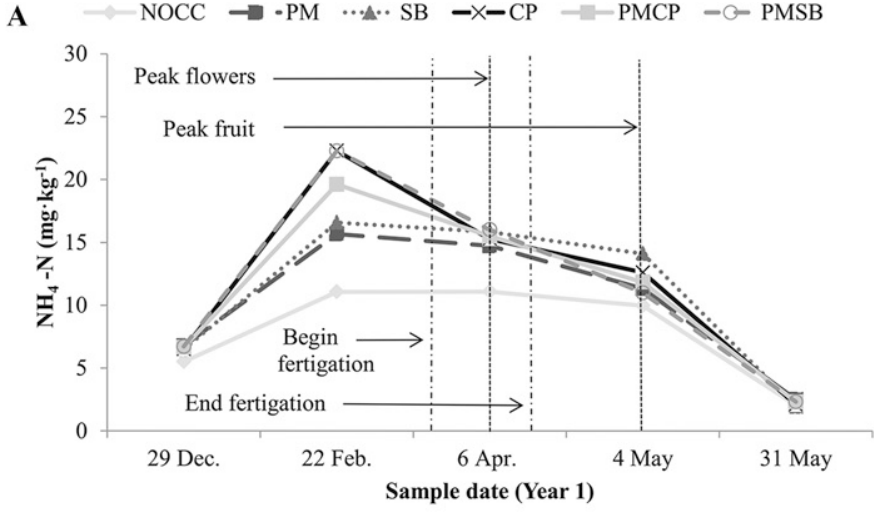

B

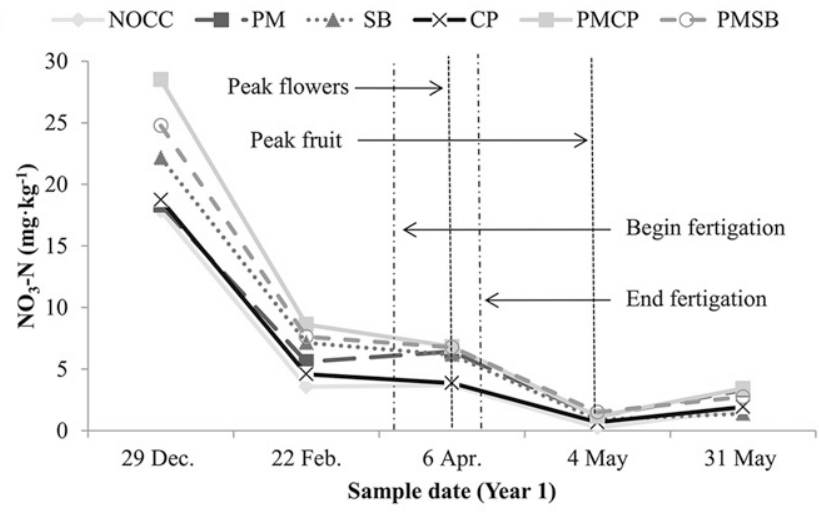

C
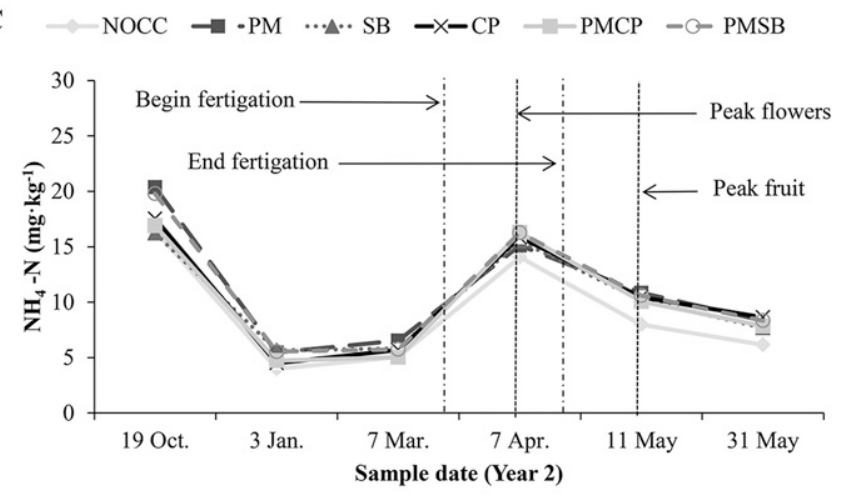

D

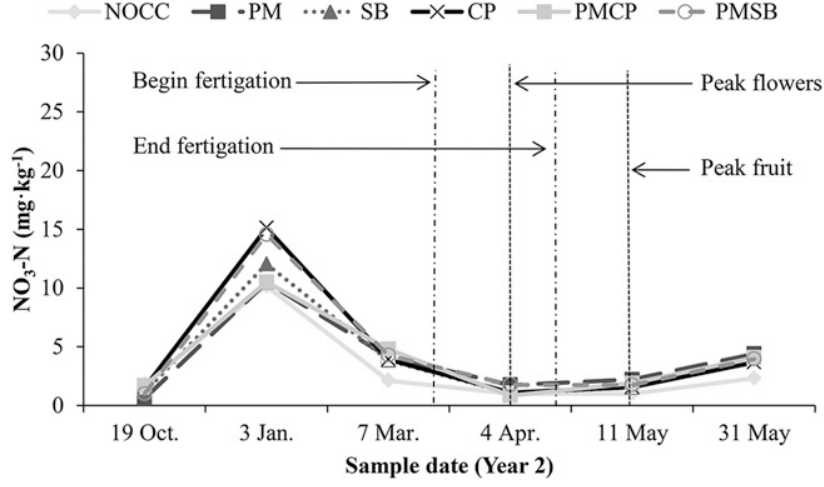

Fig. 2. Year 1 (2009-10) mean soil ammonium-nitrogen $\left(\mathrm{NH}_{4}-\mathrm{N}\right)(\mathrm{A})$ and nitrate-nitrogen $\left(\mathrm{NO}_{3}-\mathrm{N}\right)(\mathrm{B})$ levels and Year $2(2010-11)$ mean $\mathrm{NH}_{4}-\mathrm{N}(\mathrm{C})$ and $\mathrm{NO}_{3}-\mathrm{N}$ (D) levels for each cover crop treatment during the strawberry growing season. Cover crop treatments include no cover crop (NOCC), pearl millet (PM), soybean (SB), cowpea (CP), pearl millet + soybean combination (PMSB), and pearl millet + cowpea combination (PMCP). In Year 2, 7 Mar., 4 Apr., 11 May, and 31 May sample dates were not fumigated. Fertigation began on $18 \mathrm{Mar}$. and ended on 15 Apr. in Year 1 and began on 15 Mar. and ended on 12 Apr. in Year 2; $1 \mathrm{mg} \cdot \mathrm{kg}^{-1}=1 \mathrm{ppm}$. research is needed, however, to determine the holistic impacts and economic analysis of adopting these practices individually or in combination, as well as comparing these practices in fumigated and nonfumigated systems. Investigating practical soil management techniques to increase nutrient utilization, improve soil organic matter and overall soil health, in addition to yields is critical to the long-term viability of strawberry production in $\mathrm{NC}$ and the SE region.

\section{Literature cited}

Arancon, N., C.A. Edwards, and P. Bierman. 2006. Influences of vermicomposts on field strawberries: Part 2. Effects on soil microbiological and chemical properties. Bioresour. Technol. 97:831-840.

Arancon, N., C. Edwards, P. Bierman, J.D. Metzger, S. Lee, and C. Welch. 2003. Effects of vermicomposts on growth and marketable fruits of field-grown tomatoes, peppers and strawberries. Pedobiologia (Jena) 47:731-735.

Arancon, N., C. Edwards, P. Bierman, C. Welch, and J. Metzger. 2004. Influences of vermicomposts on field strawberries: 1 . Effects on growth and yields. Bioresour. Technol. 93:145-153.

Bair, K.E., J.R. Davenport, and R.G. Stevens. 2008. Release of available nitrogen after incorporation of a legume cover crop in Concord grape. HortScience $43: 875-880$.

Carroll, C., D. Charlton, and E. Tjernström. 2012. Price premiums for organic strawberries. Agr. Resource Econ. Update 15:12-14. 10 July 2014. <http:// giannini.ucop.edu/media/are-update/ files/articles/V15N6_4.pdf>.

Cheema, Z.A., M. Farooq, and A. Khaliq. 2013. Application of allelopathy in crop production: Success story from Pakistan, p. 113-143. In: Z.A. Cheema, M. Farooq, and A. Wahid (eds.). Allelopathy: Current trends and future applications. SpringerVerlag, Berlin, Germany.

Creamer, N.G. and K.R. Baldwin. 2000. An evaluation of summer cover crops for use in vegetable production systems in North Carolina. HortScience 35:600-603.

Dycus, D. 2011. General fertility program for plasticulture strawberries in eastern North Carolina. 25 May 2016. <http:// cdml6062.contentdm.oclc.org/cdm/ compoundobject/collection / pl6062coll9/id/119589/rec/9>.

Garland, B.C., M.S. Schroeder-Moreno, G.E. Fernandez, and N.G. Creamer. 2011. Influence of summer cover crops 
and mycorrhizal fungi on strawberry production in the southeastern United States. HortScience 46:985-991.

Gaskell, M., M.P. Bolda, J. Muramoto, and O. Daugovish. 2009. Strawberry nitrogen fertilization from organic nutrient sources. Acta Hort. 842:385-388.

Giller, K.E. and G. Cadisch. 1995. Future benefits from biological nitrogen fixation: An ecological approach to agriculture. Plant Soil 174:255-277.

Isk, D., E. Kaya, M. Ngouajio, and H. Mennan. 2009. Summer cover crops for weed management and yield improvement in organic lettuce (Lactuca sativa) production. Phytoparasitica 37:193-203.

Keeney, D.R. and D.W. Nelson. 1982. Nitrogen: Inorganic forms, p. 643-687. In: A.L. Page and R.H. Miller (eds.). Methods of soil analysis. Part 2. Agron. Monogr. 9. 2nd ed. Amer. Soc. Agron., Soil Sci. Soc. Amer., Madison, WI.

North Carolina Department of Agriculture Agricultural Statistics. 2012. North Carolina's rank in U.S. agriculture. 20 Mar. 2013. <http://www.ncagr.gov/stats/ crops/Ranking.pdf>.

Owen, K.J., J.P. Thompson, and T.G. Clewett. 2010. Pre-cropping with canola decreased Pratylenchus thornei populations, arbuscular mycorrhizal fungi, and yield of wheat. Crop Pasture Sci. 61:399-410.

Poling, E.B. 1993. Strawberry plasticulture in North Carolina. II. Preplant, planting, and postplant considerations for growing
'Chandler' strawberry on black plastic mulch. HortTechnology 3:383-393.

Poling, E.B., G. Krewer, and J.P. Smith. 2005. Southeast regional strawberry plasticulture production guide. 20 Mar. 2014. <http://www.smallfruits.org/ S mallFruits Reg Guide / Guides / 2005 culturalguidepartlbsl.pdf $>$.

Reganold, J.P., P.K. Andrews, J.R. Reeve, L. Carpenter-Boggs, C.W. Schadt, J.R. Alldredge, C.F. Ross, N.M. Davies, and J. Zhou. 2010. Fruit and soil quality of organic and conventional strawberry agroecosystems. PLoS One 5(9):e12346, doi: 10.1371/journal.pone.0012346.

Sarr, P.A., M. Khouma, M. Sene, A. Guisse, A.N. Badiane, and T. Yamakawa. 2008. Effect of pearl millet-cowpea cropping systems on nitrogen recovery, nitrogen use efficiency and biological fixation using the ${ }^{15} \mathrm{~N}$ tracer technique. Soil Sci. Plant Nutr. 54:142-147.

Sarrantonio, M. 2007. Building soil fertility and tilth with cover crops, p. 16-24. In: A. Clark (ed.). Managing cover crops profitably. Sustainable Agr. Network, Beltsville, MD.

Singh, R., R.K. Gupta, R.T. Patil, R.R. Sharma, and S. Kumar. 2008. Vermicompost substitution influences growth, physiological disorders, fruit yield and quality of strawberry (Fragaria $\mathrm{x}$ ananassa Duch.). Bioresour. Technol. 99:85078511.

Snapp, S.S., S.M. Swinton, R. Labarta, D. Mutch, J.R. Black, R. Leep, J. Nyiraneza, and K. O'Neil. 2005. Evaluating cover crops for benefits, costs and performance within cropping system niches. Agron. J. 97:322-332.

Sydorovych, O., P.M. Brannen, D.M. Monks, F.J. Louws, G.E. Fernandez, C.D. Safley, L.M. Ferguson, and E.B. Poling. 2006. Economic evaluation of methyl bromide alternatives for the production of strawberries in the southeastern United States. HortTechnology 16:118128 .

U.S. Department of Agriculture (USDA). 2015. Agricultural statistics for 2014. U.S. Dept. Agr., Washington, DC.

Wang, G., C.M. Hutchinson, M.E.J. McGiffen, and M. Ngouajio. 2008. Summer cover crop and in-season management system affect growth and yield of lettuce and cantaloupe. HortScience 43:13981403.

Wang, Q.R., W. Klassen, Y.C. Li, M. Codallo, and A. Abdul-Baki. 2005. Influence of cover crops and irrigation rates on tomato yields and quality in a subtropical region. HortScience 40:21252131.

Wang, Q., M. Codallo, Y. Li, and W. Klassen. 2009. Cover crops and organic mulch to improve tomato yields and soil fertility. Agron. J. 101:345-351.

Werner, M.R., R.A. Kluson, and S.R. Gliessman. 1990. Colonization of strawberry roots by VA mycorrhizal fungi in agroecosystems under conventional and transitional organic management. Biol. Agr. Hort. 7:139-151.

Weston, L.A. 1996. Utilization of allelopathy for weed management in agroecosystems. Agron. J. 88:860-866. 